\title{
JURNALISME WARGA DAMPAK TSUNAMI DI ACEH (STUDI KASUS MEULABOH)
}

\author{
Muzakkir \\ Universitas Teuku Umar: \\ muzakkir@utu.ac.id
}

\begin{abstract}
The article is a study in the background with observations of good citizen journalism, by preaching information that can provide positive value for the development of publications. Not a stove that always heats the situation and situation. "Citizen journalism" is arguably the most recent finding in the current journalistic domain. A term where people intervene to share information is like a reporter. Various sources view differently about who actually started this trend. There are sources who say citizen journalism was pioneered by the tsunami of 26 December 2004 in Aceh. At that time, Acehnese people through a personal documentation video recorded water scenes that devastated Aceh and its surroundings. These videos play an important role in the supply of news for mainstream / mainstream media. There is another source who mentions that one of the private television sets opened video shipments of citizens who reported the incident in their respective homes through their own citizen journalism platform. Whatever claims to who initiates "Citizen Journalism", mainstream media seems to be seriously working on this fairly new market share. All may be one view that the future of the journalistic world is in "Citizen Journalism". A distinctive feature of citizen journalism lies in the framing of the news. Framing is a term in the world of journalism about how a media frame / construct / process the reality that occurs in society into a story, which is certainly in line with the tendency of the media concerned. In the case of citizen journalism which positions itself as a freestanding reporter, it is not bound by any media institution. From there, a personal framing is formed, which is nothing but the framing of the citizen itself which incidentally tends to construct reality in the field without any inclination. That is to say, something that is not reduced or exaggerated for certain purposes. The earthquake in Meulaboh was reported not only to have caused a tsunami in the western region of Aceh, but also struck the island of Sabang. At that time, the Satlak for Disaster Management and Refugee (PBP) Region III of West Aceh, until March 13, 2005 reported that the death toll reached 12,873 people, 2,403 people missing and 73,915 people displaced.
\end{abstract}

Keyword: : Journalisme, Citizen, dan Tsunami

\section{A. PENDAHULUAN}

Jurnalisme warga (partisipatoris) adalah pengumpulan, pelaporan, analisis dalam penyebaran berita dan informasi oleh masyarakat biasa non wartawan professional. Jurnalisme warga merupakan kegiatan kewartawanan dalam bentuk partisipasi aftif yang dilakukan oleh masyarakat dalam kegiatan pengumpulan, pelaporan, analisa serta penyampaian informasi dan berita. Perkembangan jurnalisme warga di Indonesia dipicu ketika pada tahun 2004 terjadi tragedi Tsunami di Aceh yang diliput sendiri oleh korban tsunami. Terbukti berita langsung dari korban dapat mengalahkan berita yang dibuat oleh jurnalis profesional. 
Hampir semua stasiun TV mempunyai segmen berita yang menayangkan liputan dari para warga yang lebih dikenal dengan citizen journalim (jurnalisme warga). Mulailah menjadi jurnalis warga yang baik, dengan mengabarkan informasi yang bisa memberi nilai positif bagi perkembangan berita. Bukan jadi kompor yang selalu memanasi situasi dan keadaan. "Jurnalisme warga" boleh dibilang temuan paling mutakhir dalam ranah jurnalistik saat ini. Sebuah istilah dimana warga turun tangan membagikan informasi tak ubahnya pewarta. Pelbagai sumber berpandangan beda tentang siapa yang sebenarnya memulai tren ini. Ada sumber yang mengatakan jurnalisme warga dirintis akibat bencana tsunami, 26 Desember 2004 silam di Aceh. Pada saat itu, warga Aceh lewat video dokumentasi pribadi merekam adegan air yang meluluhlantakkan Aceh dan sekitarnya. Video-video tersebut berperan penting dalam hal pasokan berita untuk media arus utama/mainstream. Ada lagi sumber yang menyebut bahwa salah satu televisi swasta yang membuka kiriman-kiriman video warga yang memberitakan kejadian di tempat tinggalnya masing-masing lewat platform jurnalisme warga bikinan mereka.

Kata-kata tsunami dipisah menjadi dua yaitu tsu dan nami. Dalam bahasa jepang, tsu artinnya pelabuhan dan nami disebut gelombang. Tsunami berarti gelombang besar di pelabuhan. Secara umum tsunami berarti perpindahan badan air yang disebabkan oleh perubahan permukaan laut secara vertikal secara tiba-tiba. Perubahan itu, disebabkan oleh gempa bumi yang berpusat di bawah laut, letusan gunung berapi bawah laut, longsor bawah laut, atau hantaman meteor di laut. Gempa besar 26 Desember 2014, di Aceh dan sekitarnya dengan kekuatan 9,1 sampai 9,3 skala richter (SR) mengguncang dasar laut di Barat Daya Sumatra sekitar 20-15 kilometer lepas pantai. "Sehari berselang PBB menyatakan tsunami di Aceh sebagai bencana kemanusiaan terbesar yang pernah terjadi, dan menelan korban tewas mencapai 230.000 jiwa", data tribunstyle.com dari DW.com.

Gelombang tsunami bisa melebar ke segala arah. Kecepatan gelombang tsunami yang terjadi di Aceh mencapai 400 kilometer per jam dengan ketinggian gelombang tsunami 24 meter saat menghantam daratan, kemudian meninggi hingga 30 meter di sejumlah daerah ketika menyapu daratan. Beberapa lempeng bumi bertemu dan beradu atau berbenturan sejak dahulu, di kepulauan Indonesia ini. Banyak tempat rawan akan gempa dan tsunami di Indonesia. Hal ini dikarenakan wilayah Indonesia secara geografis maupun geologi merupakan negara kepulauan yang terletak pada empat lempeng tektonik yang bertemuan, yaitu: lempeng Euroasia, Australia, Pasifik, dan Filipina. Bencana gempa bumi dan gelombang tsunami yang melanda Nanggroe Aceh Darussalam dan Sumatra Utara tanggal 26 Desember 2004 lalu sangatlah luar biasa. Hempasan ombak yang merasuk jauh ke pantai menghancurkan daratan. Kota-kota yang terletak di sepanjang pantai Barat Aceh dan Sumatra Utara, terutama dari Banda Aceh hingga Meulaboh, dibuat porak poranda. 
Dengan demikian, laju gelombang tidak terasa oleh kapal yang sedang berada di tengah laut. Ketika mendekati pantai, kecepatan gelombang tsunami menurun hingga sekitar $30 \mathrm{~km}$ per jam, namun ketinggiannya sudah meningkat hingga mencapai puluhan meter. Hantaman gelombang tsunami bisa masuk hingga puluhan kilometer dari bibir pantai. Kerusakan dan korban jiwa yang terjadi karena tsunami bisa diakibatkan karena hantaman air maupun material yang terbawa oleh aliran gelombang tsunami.

Dampak negatif yang diakibatkan tsunami adalah merusak apa saja yang dilaluinya. Bangunan, tumbuh-tumbuhan, dan mengakibatkan korban jiwa manusia serta menyebabkan genangan, pencemaran air asin lahan pertanian, tanah, dan air bersih. Sejarawan Yunani bernama Thucydides merupakan orang pertama yang mengaitkan tsunami dengan gempa bawah lain. Namun hingga abad ke-20, pengetahuan mengenai penyebab tsunami masih sangat minim. Penelitian masih terus dilakukan untuk memahami penyebab tsunami. Teks-teks geologi, geografi, dan oseanografi di masa lalu menyebut tsunami sebagai gelombang laut seismic.

\section{B. METODE PENELITIAN}

Studi yang lakukan pada karya ini dasarnya adalah riset lapangan (field research). Sumber data penelitian ini berdasarkan penelitian kualitatif yang tidak memerlukan pengetahuan mendalam akan literatur yang digunakan dan kemampuan tertentu dari pihak peneliti, dengan mengandalkan sumbersumber primer yang terkait dengan pokok-pokok masalah.

Pendekatan yang digunakan dalam penelitian ini adalah pendekatan historis, dan multidisipliner. Setelah itu, data yang telah ada, penulis analisis dengan menggunakan metode komparatif dalam paradigma kualitatif. Tujuannya untuk mencari titik persamaan dan perbedaan sehingga dapat menghasilkan kesimpulan yang dapat dipertanggungjawabkan secara ilmiah.

Dalam studi ini, juga digunakan metode kualitatif berkaitan erat dengan paradigma interpretatif dapat dilihat dalam beberapa karakteristiknya:

a. Riset kualitatif berfokus pada kata, bukannya angka. Dalam riset dengan menggunakan metode ini dilakukan pengamatan dan wawancara dengan korban bencana tsunami terhadap suatu keadaan atau kejadian.

b. Keterlibatan peneliti; instrument utama riset kualitatif adalah peneliti terlibat dekat dengan orang-orang yang diteliti. (Christine Daymon, 2008).

\section{Rumusan Masalah}

Tulisan ilmiah ini dapat dikelompokkan berdasarkan uraian; jurnalisme warga, dampak tsunami, kerusakan akibat tsunami, dan cara menanggulangi pasca tsunami dalam Wilayah Meulaboh-Kabupaten Aceh Barat 


\section{Sasaran}

Sasarannya agar bisa mengidentifikasi, mempelajari dan memahami dampak bencana tsunami, karusakan yang berimbas pada lingkungan kesehatan korban tsunami. Upaya penanggulangan pasca tsunami khususnya di Meulaboh-Kabupaten Aceh Barat.

\section{HASIL DAN PEMBAHASAN}

Ternyata selama ini kita sering kali menjadi jurnalisme warga. Ketika kita melihat kejadian yang menurut kita bisa menjadi berita yang bisa di share ke teman-teman atau warga yang lain. Dengan bermodalkan smartphone atau hape berkamera dan sedikit keterangan foto atau caption atau berita pendek. Maka disaat itulah kita sudah menjadi jurnalisme warga. Dengan menjadi jurnalisme warga, sebenarnya kita juga bisa mengontrol bagi pemegang kebijakan atau bagi stakeholder lainnya agar bisa menjalankan kebijakannya dengan baik. Pewarta adalah pembaca, khalayak ramai, atau siapapun yang mempunyai informasi atas sesuatu. Siapa pun dapat memberikan komentar, koreksi, klarifikasi atas berita yang diterbitkan,

Hal yang menjadi prinsip jurnalisme adalah memiliki komunitas-komunitas yang sering melakukan gather, walaupun ada kritik, tidak ada persaingan antar penulis (reporter), tidak membedakan pewarta profesional atau amatir, tidak ada seleksi ketat terhadap berita-beritanya, ada yang dikelola secara profesional ada pula yang dikelola secara amatir, pembaca dapat langsung berinteraksi dengan penulisnya melalui kotak komentar atau e-mail.

\section{Sisi Kelebihan Jurnalisme Warga}

Ada empat sisi kelebihan jurnalisme warga (citizen journalism):

1. Citizen journalist adalah orang yang memiliki kamera digital atau kamera ponsel dan menyunting karya mereka, seperti peristiwa utama (tsunami)

2. Citizen journalist adalah orang yang ingin menemukan komunitas lokal atau cyber community dan memproduksi tulisan tentang komunitasnya;

3. Citizen journalist adalah orang yang mengkritisi dan mengkampanyekan sebab-sebab terjadinya peristiwa

4. Citizen journalism adalah orang yang berpartisipasi ke dalam sebuah percakapan dengan para jurnalis profesional dan para pemilik blog.

Tidak ada yang meragukan bahwa sesuatu yang baru telah muncul dan kantor berita tradisional harus setuju dengan citizen journalist. Akan tetapi, esensi citizen journalism telah menggantikan jurnalisme 
tradisional yang dianggap mati. Para citizen journalist adalah bagian dari keluarga. Dan perbedaannya terletak pada sebutan yang diberikan kepada mereka, yaitu "intelegensi kolektif”. Bagi seorang jurnalis, kantor berita adalah ekspresi intelegensi kolektif dengan hubungan horizontal antara kolega, tetapi juga memiliki hubungan vertikal dengan editor. Ada juga yang mempertanyakan bagaimana mempertanggungjawabkan kebenaran informasi yang ditulis oleh orang biasa? Bagaimana jurnalisme publik bisa dipercaya? Bagaimana mengelola kredibilitas? Terkadang kita tidak bisa memastikan kebenaran informasi yang berasal dari citizen journalist. Kita tidak bisa percaya begitu saja kepada karya mereka. Ada fungsi jurnalisme yang hilang dan konsep citizen journalis, yaitu verifikasi. Siapa saja bisa mengirmkan karya jurnalistiknya tanpa melalui proses verifikasi.

Siapa yang diuntungkan? Banyak orang yang merasa tidak bisa menggunakan blog, karena mereka merasa tidak akrab dengan Informasi Teknologi (IT). Padahal, isi dari blog tidak adanya hubungannya dengan IT. Setiap orang dapat menulis apapun. Inilah hal yang penting bagi masyarakat, bahwa mereka disajikan beragam piliham untuk dipiih. Di sini juga lah letak keindahan citizen journalism, semuanya dikembalikan pada masyarakat.

Perkembangan teknologi informasi juga mengubah hakekat media. Dengan internet, kini berkembang situs-situs lembaga maupun pribadi. Selain itu, berkembang juga weblog ataublog, di mana setiap orang bisa melaporkan peristiwa di sekelilingnya, atau paling tidak, melaporkan gagasannya kepada publik. Dengan demikian, kalau dulu media didirikan oleh lembaga, atau individu yang mempunyai uang dan kekuasaan (power), kini setiap individu bisa membuat media. Karena itu, di zaman internet ini, setiap individu juga adalah media.

Kalau ditanya siapa secara politis yang dapat keuntungan dari blog, maka keuntungan ini bisa kita kategorikan menjadi 3 (tiga) hal: finansial, sikap politis, dan keuntungan dari sisi negatif. Untuk keuntungan finansial mungkin agak sulit karena blog pada dasarnya tidak ada aspek komersil, akan tetapi keuntungan itu dalam bentuk lain yaitu publisitas. Kalau keuntungan dari sisi negatif, maksudnya adalah orang-orang yang ingin mengacau, bisa saja melakukan hal tersbut. Kadang-kadang ada orang yang menulis di blognya dan mengutip blog orang lain tanpa menyebut sumber kutipannya. Bagaimana seharusnya sikap terhadap hal seperti ini? Kita bebas mengutip blog orang lain, dan orang lain bebas mengutip blog kita. Apabila tidak disebut, tidak masalah juga. Kalau nama kita disebut, ya itu keuntungan buat kita.

\section{Memahami Tsunami}

Tsunami adalah rangkaian gelombang laut yang mampu menjalar dengan kecepatan hingga lebih 900 km per jam, terutama diakibatkan oleh gempa bumi yang terjadi di dasar laut. Kecepatan gelombang tsunami bergantung pada kedalaman laut. Di laut dengan kedalaman $7000 \mathrm{M}$ misalnya, kecepatannya bisa mencapai 942,9 km/jam. Kecepatan ini hampir sama dengan kecepatan pesawat jet. Namun demikian tinggi gelombangnya di tengah laut tidak lebih dari $60 \mathrm{~cm}$. Akibatnya kapal-kapal yang sedang berlayar diatasnya 
jarang merasakan adanya tsunami. Berbeda dengan gelombang laut biasa, tsunami memiliki panjang gelombang antara dua puncaknya lebih dari $100 \mathrm{~km}$ di laut lepas dan selisih waktu antara puncak-puncak gelombangnya berkisar antara 10 menit hingga $1 \mathrm{jam}$. Saat mencapai pantai yang dangkal, teluk,atau muara sungai gelombang ini menurun kecepatannya, namun tinggi gelombangnya meningkat puluhan meter dan bersifat merusak.

\section{Bencana tsunami}

Tidak hanya Indonesia yang mengalami kerusakan akibat gempa 8,9 skala richter dengan episentrum di sekitar Meulaboh itu, tetapi juga negara-negara yang terletak di teluk Banggali dan juga jauh hingga Benua Afrika. Gempa bumi ini tergolong terbesar keempat sepanjang sejarah. Peristiwa atau rangkaian peristiwa yang mengancam dan mengganggu kehidupan dan penghidupan masyarakat yang disebabkan, baik oleh faktor alam dan/atau faktor non alam maupun faktor manusia sehingga mengakibatkan timbulnya korban jiwa manusia, kerusakan lingkungan, kerugian harta benda dan dampak psikologis. Masyakarat terkoyak, mata pencaharian hilang, keluarga, sekolah dan fasilitas kesehatan hilang terbawa arus besar. Selain itu, terdapat kerusakan skala besar dan sumber daya yang besar pula. Sehingga membutuhkan waktu yang relatif lama dalam rehabilitasi daerah tersebut dan memulihkan dengan lebih baik. Efek dari gempa bumi dan tsunami ini bukan hanya seketika, tetapi mendunia. Istilah tsunami begitu sering diungkapkan oleh warga. Selain itu dampak buruk tsunami yang diakibatkan oleh gelombang yang sangat dahsyat dengan ketinggian ketika masuk ke daratan bisa mencapai 15 meter dan kecepatan bagai pesawat tempur. Keadaan pesisir pantai pasca tsunami mengalami kerusakan, sebagian besar vegetasi pelindung kawasan pesisir mati akibat hantaman gelombang. Vegetasi yang mati meliputi hutan mangrove, hutan pantai dan hutan hujan tropis dataran rendah.

Bencana yang diakibatkan oleh peristiwa atau serangkaian peristiwa yang disebabkan oleh alam antara lain berupa gempa bumi, tsunami, gunung meletus, banjir, kekeringan, angin topan dan tanah longsor. Daerah rawan bencana yaitu suatu daerah yang memiliki risiko tinggi terhadap suatu bencana akibat kondisi geografis, geologis, dan demografis serta akibat ulah manusia. Sedangkaan rawan bencana merupakan kondisi atau karakteristik geologis, biologis, hidrologis, klimatologis, geografis, sosial, budaya, politik, ekonomi, dan teknologi pada suatu wilayah untuk jangka waktu tertentu yang Pedoman Teknis xvi Penanggulangan Krisis Kesehatan Akibat Bencana mengurangi kemampuan mencegah, meredam, mencapai kesiapan, dan mengurangi kemampuan untuk menanggapi dampak buruk bahaya tertentu.

\section{SekilasSejarah Tsunami 1755 dan 1877}

Gempa bumi besar pada 1 November 1755 diLisbon, pukul 10 pagi. Gempa itu berlangsung sekitar 5 hingga 8 menit dengan kekuatan 8, 75 SR. Gempa itu sangat kuat hingga berdampak dirasakan sampai ke Inggris. Di Inggris, Viscount Parker F.R.S memperhatikan gangguan air di sudut barat daya parit yang mengelilingi Kastil Shirburn, di Oxfordshire. Hampir segera 
setelah gempa itu, timbullah tsunami yang sangat besar dan kuat di Lisbon. Laut tampak surut, dan datanglah gelombang besar dengan gemuruh menembus masuk ke kota sampai sejauh 750 meter bergerak cepat melewati jalan-jalan dan menggenangi rumah-rumah. Jembatan-jembatan ambruk, dinding-dinding roboh dan tumpukan sampah reruntuhan hanyut terbawa ke lepas pantai. Di Kastil Belem, gelombang diperkirakan setunggi 16, 6 meter . Ribuan orang yang selamat dari gempa bumi tersapu hanyut dan tenggelam dihantam tsunami. Kerusakan terparah terjadi di Lisbon, korban jiwa tewas yang resmi mencapai 50.000 orang.

Pada 9 Mei 1877, gempa bumi besar terjadi di pesisir Amerika Selatan, antara Peru dan Cile. Gelombang tsunami pertama mencapai Hilo dalam kegelapan menjelang fajar 10 Mei 1877. Kepala Polisi Luther Severance mengingat kembali peristiwa alam yang dahsyat pada hari itu. "Kami telah mengalami bencana besar di Hilo. Pada Kamis pagi, 10 Mei 1877, sekitar pukul 4 pagi, laut tampak pasang dan surut tidak sepertibiasanya, kemudian pada pukul 5 pagi gelombang menghempas hampir seluruh toko di bagian depan kota, membawa sejumlah besar potongan kayu dan seluruh dinding batu makai (pada sisi laut) di dermaga. Tetapi di Waiakea kerusakannya menakutkan; setiap rumah dalam jarak 90 meter dari laut tersapu bersih. Dermaga Kapal Uap dan Gudang Pelabuhan, Gudang Spencer, jembatan diatas sungai kecil, dan semua rumah kediaman tersapu dalam sekejap dan sekarang menjadi reruntuhan yang jauh di darat”, tulis Walter C. Dudley

Saat itu, Kapal penangkap ikan paus Amerika, Pasific, telah berlabuh di Teluk Hilo pada air laut sedalam 8 meter. Ketika itu air surut, kapal itu tampak berada di tempat tinggi dan ketika air laut pasang kembali, kapal ini berputar-putar. Semua orang mengira Kapal itu akan terseret dan terdampar di Pantai. Namun, ternyata Kapal itu selamat. Pemiliknya, Kapten Smithers seperti Kapten Lawrence 44 tahun sebelumnya, mengirimkan perahu-perahu panjangnya menuju ke Teluk untuk menyelamatkan orang-orang yang tak berdaya yang sedang berenang untuk menyelamatkan diri mereka dari pusaran air laut. Dengan berlutut, Pendeta Coan memanjatkan doa dengan sungguh-sungguh. Korban seluruhnya di Hilo sebanyak 5 orang meningggal, 17 orang luka berat, 37 rumah hancur, 163 orang hilang tempat tingga dan 17 kuda dan keledai tenggelam. Tsunami yang terjadi menghantam Kepulauan Hawaii dengan kekuatan yang dahsyat pada tahun 1837, 1868, 1877 dan 1946 semuanya berkaitan dengan gempa bumi yang besar.

Indonesia dikenal sebagai negara kaya bencana gempa bumi, tsunami, maupun letusan gunung berapi dan lain-lain. Sejarah bencana yang tergolong besar di Indonesia seperti pada 27 Agustus 1983 terjadi bencana alam berupa meletusnya gunung Krakatau di Selat Sunda. Selain itu, sejarah baru ditorehkan yaitu bencana alam gempa besar di Aceh pada 26 December 2004, mengakibatkan tsunami berskala 8, 7 pada skala richter di Barat Aceh dan oleh dua gempa besar di Kepulauan Nicobar dan Andaman, India, yang terjadi dalam selang waktu dua jam kemudian. Bencana ini menewaskan sekitar 150.000 penduduk di kawasan Asia Tenggara dan Asia Selatan.

\section{Gempa Dalam Kajian Islam}

Allah SWT dalam Alquran telah menjelaskan tentang bumi yang bergerak dan sering menimbulkan gempa bumi. Allah SWT memberi beberapa isyarat dan petunjuk, misalnya dalam QS az-Zalzalah (99:1- 
4), "Apabila bumi digoncangkan dengan goncangan (yang dahsyat), dan bumi telah mengeluarkan bebanbeban berat yang dikandungnya, dan manusia bertanya: "Mengapa bumi (menjadi begini)?", pada hari itu bumi menceritakan beritanya, karena sesungguhnya Tuhanmu telah memerintahkan (yang sedemikian itu) kepadanya. Pada hari itu manusia ke luar dari kuburnya dalam keadaan bermacam-macam, supaya diperlihatkan kepada mereka (balasan) pekerjaan mereka. Barangsiapa yang mengerjakan kebaikan seberat dzarrahpun, niscaya dia akan melihat (balasan)nya. Dan barangsiapa yang mengerjakan kejahatan sebesar dzarrahpun, niscaya dia akan melihat (balasan)nya pula. QS az-Zalzalah (99:1-4).

Menurut para ahli, gempa adalah peristiwa alami berupa gerakan dalam tubuh bumi. Kata pakar, tiap tahun lempengan bumi bergeser beberapa sentimeter. Di sisi lain, kita juga harus ingat bahwa Allahlah yang menguasai semua proses di dunia ini. Apakah Allah tidak mampu menggerakkan lempengan bumi secara lembut sehingga tidak ada korban dan kerusakan? Tentu saja, Allah mampu melakukannya. Jika demikian, gempa yang terjadi selama ini tentulah bukan peristiwa alami biasa. "Allah pernah memberikan azab kepada manusia pada zaman Nabi Shaleh (7:77 dan 7:78). Kemudian mereka sembelih unta betina itu, dan mereka berlaku angkuh terhadap perintah Tuhan. Dan mereka berkata: "Hai Shaleh, datangkanlah apa yang kamu ancamkan itu kepada kami, jika (betul) kamu termasuk orang-orang yang diutus (Allah). Karena itu mereka ditimpa gempa, maka jadilah mereka mayat-mayat yang bergelimpangan di tempat tinggal mereka. Allah pernah memberikan azab kepada manusia pada zaman Nabi Syu'aib. (29:36 dan 29:37).

Kita harus belajar dari kisah para Nabi. Allah menjadikan kisah umat yang dihukum pada zaman Nabi Musa sebagai pelajaran bagi kita semua dan Fir'aun mempengaruhi kaumnya (dengan perkataan itu) lalu mereka patuh kepadanya. Karena sesungguhnya mereka adalah kaum yang fasik. Maka tatkala mereka membuat Allah murka, Allah SWT menghukum mereka lalu kami tenggelamkan mereka semuanya di laut). Allah jadikan mereka sebagai pelajaran dan contoh bagi orang-orang yang kemudian. Tentu saja, kita juga harus belajar dari kisah semua Nabi dalam Al Qur'an, termasuk kisah Nabi Syu'aib berikut ini.

Kisah Nabi Syu'aib dalam Surat Al A'raaf: 7:85. Dan (Kami telah mengutus) kepada penduduk Madyan saudara mereka, Syu'aib. Ia berkata: "Hai kaumku, sembahlah Allah, sekali-kali tidak ada Tuhan bagimu selain-Nya. Sesungguhnya telah datang kepadamu bukti yang nyata dari Tuhanmu. Maka sempurnakanlah takaran dan timbangan dan janganlah kamu kurangkan bagi manusia barang-barang takaran dan timbangannya, dan janganlah kamu membuat kerusakan di muka bumi sesudah Tuhan memperbaikinya. Yang demikian itu lebih baik bagimu jika betul-betul kamu orang-orang yang beriman." Dan janganlah kamu duduk di tiap-tiap jalan dengan menakut-nakuti dan menghalang-halangi orang yang beriman dari jalan Allah, dan menginginkan agar jalan Allah itu menjadi bengkok. Dan ingatlah di waktu 
dahulunya kamu berjumlah sedikit, lalu Allah memperbanyak jumlah kamu. Dan perhatikanlah bagaimana kesudahan orang-orang yang berbuat kerusakan. (Al A`raaf: 7:86). Pemuka-pemuka kaum Syu'aib yang kafir berkata (kepada sesamanya): "Sesungguhnya jika kamu mengikuti Syu'aib, tentu kamu jika berbuat demikian (menjadi) orang-orang yang merugi." Kemudian mereka ditimpa gempa, maka jadilah mereka mayat-mayat yang bergelimpangan di dalam rumah-rumah mereka. (7:90-91)

Menurut peta sejarah kegempaan Badan Meteorologi dan Geofisika, gempa berskala kecil dan besar banyak melanda Indonesia, mulai dari Nusa Tenggara hingga Sumatera. Pusat gempa sebagian besar di perairan yang relatif dekat dengan pulau-pulau tersebut. Hal ini berhubungan dengan adanya pertemuan lempeng benua di dasar laut, dan diketahui bahwa sebagai tempat bertemunya tiga lempeng benua terdapat di bawah perairan Indonesia. tiga lempeng benua tersebut ialah, lempeng Hindia atau Indo-Australia di sebelah selatan, lempeng Eurasia di utara, dan lempeng Pasifik di timur.

Gempa yang terjadi di Perairan Barat Provinsi Aceh, Nicobar, dan Andaman, hari minggu 26 Desember 2004, lalu merupakan akibat dari interaksi lempeng Indo-Australia dan Eurasia. Gempa-gempa besar pada skala magnitudo 5,8 hingga 9,0 berpusat di dasar laut pada kedalaman 10 kilimeter tergolong gempa dangkal, namun telah menimbulkan gelombang tsunami yang menerjang wilayah pantai di Asia Tenggara dan Asia Selatan, yang berada di sekitar tiga pusat gempa tersebut Gempa berskala besar, kata Dr.Prih Haryadi kepala Pusat Sistem Data dan Informasi Geofisika Badan Meteorologi dan Geofisika (BMG), menimbulkan patahan berdimensi ratusan kilometer jaraknya dari pusat gempa hingga memicu gempa lain. Gempa di Aceh menimbulkan dampak kegempaan hingga radius 200 kilometer. Diantaranya memicu gempa di Kepulauan Nicobar di sebelah utara pusat gempa pada jarak 550 kilometer serta mengguncang Pulau Andaman. Selain menimbulkan getaran yang kuat, gempa kali ini juga menyebabkan timbulnya deformasi vertikal di sumber gempa. Deformasi berupa penurunan permukaan dasar laut tersebut mengakibatkan penjalaran energi kinetik menjadi gelombang tsunami di pantai. Daerah yang rawan tsunami adalah daerah yang berpantai landai dan berupa teluk. Pada daerah teluk, energi gelombang terperangkap hingga naik ke darat. Ancaman gempa tsunami berada sepanjang pertemuan lempeng mulai dari timur kepulauan Maluku, selatan Nusa Tenggara dan Jawa, hingga barat Sumatera. Umumnya, gempa subduksi di laut yang berkekuatan minimal 6,2 pada skala richter sudah dapat menimbulkan gelombang tsunami. Namun, yang lebih kecil dari itupun dapat menimbulkan gelombang pasang, bergantung pada lokasinya dan pola subduksi serta topografi dasar laut.

\section{Gempa dan Dampak Tsunami di Meulaboh}

Gempa di Meulaboh, bukan saja telah menimbulkan tsunami di Daerah Barat, Provinsi Aceh, tetapi juga menerjang pulau Sabang. Gempa di Nicobar yang berkekuatan 7,3 skala richter ini yang dipicu oleh 
gempa Meulaboh-Aceh Barat, dan gempa tersebut pula menyebabkan timbulnya tsunami di Songla dan Phuket (Thailand). Menurut perkiraan Kepala Pusat Penelitian Geoteknologi LIPI, Dr. Heri Haryono, gempa yang posisinya di dekat Pulau Simeulue (Aceh) itu terjadi karena mekanisme kompresi atau subduksi, yaitu lempeng Samudra Hindia yang menerjang bagian bawah lempeng Asia Tenggara (yang merupakan subduksi lempeng Benua Eurasia). Karena hal yang terjadi adalah gempa subduksi, yang menyebabkan menurunnya permukaan dasar laut di tempat pertemuan lempeng tersebut, maka akan timbul gelombang laut yang merambat dan menerjang pantai di dekatnya.

Bencana gempa dan tsunami mengakibatkan Kabupaten Aceh Barat mengalami kerusakan dan kehancuran total pada empat kecamatan yang terletak di sepanjang Pesisir Barat Samudra Indonesia yaitu Kecamatan Johan Pahlawan, Meureubo, Samatiga dan Arongan Lambalek. Kecamatan Meureubo, Samatiga, dan Arongan Lambalek yang letaknya di Selatan dan Utara Kota Meulaboh, cakupan wilayah akibat tsunami ini meliputi semua gampong yang berada di sepanjang pesisir pantai yaitu Kecamatan Meureubo sabanyak 16 gampong, Samatiga 16 gampong dan Arongan Lambalek 13 gampong

Berdasarkan Sensus Penduduk Aceh-Nias (SPAN) pasca gempa bumi dan gelombang tsunami 2005, jumlah penduduk Kabupaten Aceh Barat tercatat 150. 450 jiwa, 76.932 jiwa laki-laki, dan 73.518 jiwa perempuan. Jumlah penduduk ini apabila dibandingkan dengan nilai rilis SPAN pada akhir tahun 2003, telah terjadi penurunan penduduk yang sangat signifikan dari sebelumnya 176.586 jiwa dengan komposisi 87.570 jiwa (49,59 persen) laki-laki dan 89.016 jiwa (50,41 persen) perempuan. Sementera dari Satlak Penanggulangan Bencana dan Pengungsi (PBP) Wilayah III Meulaboh-Aceh Barat saat itu, hingga 13 Maret 2005 jumlah korban yang meninggal mencapai 12.873 jiwa, korban hilang sebanyak 2.403 jiwa dan yang mengungsi mencapai 73.915 jiwa.

\section{Masa Tanggap Darurat}

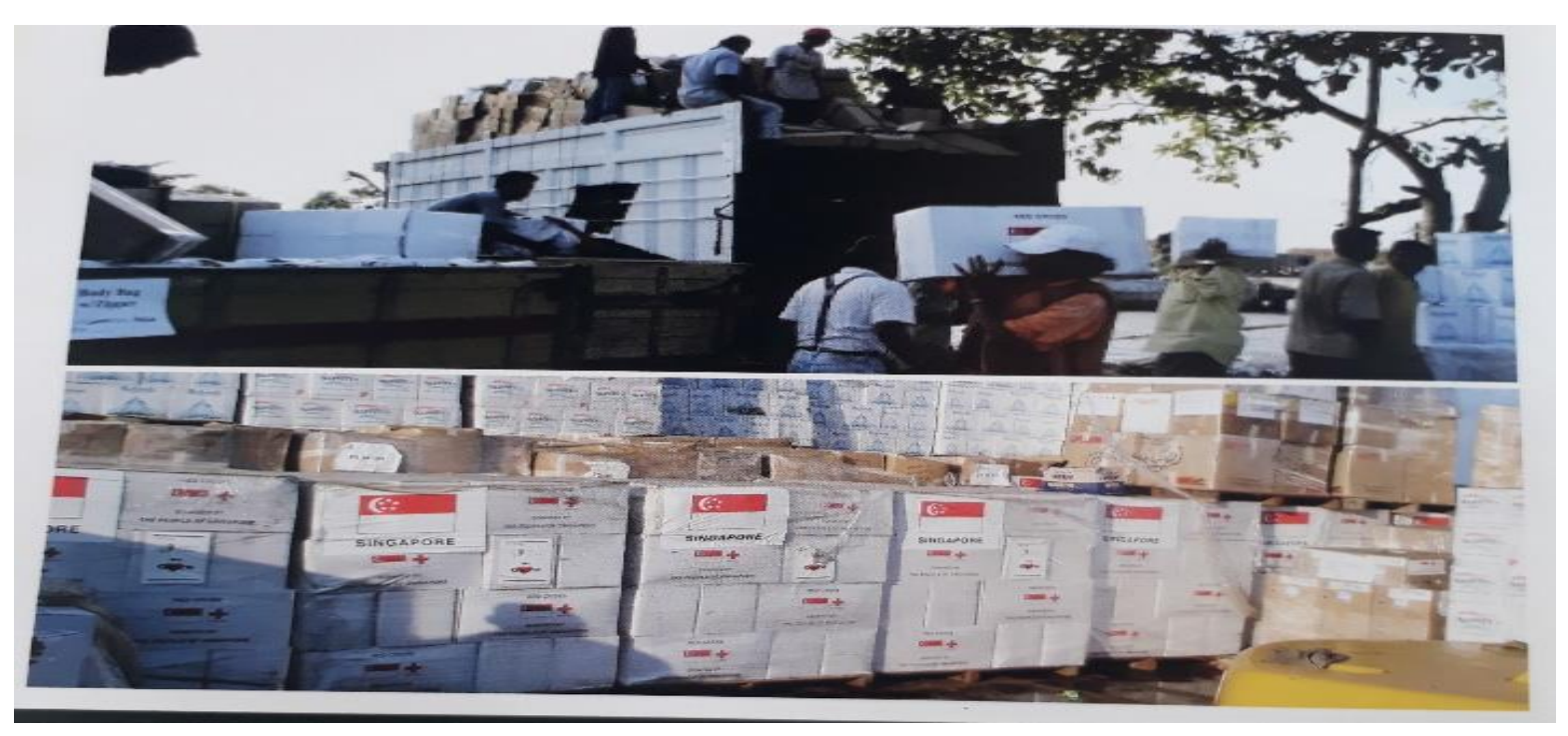




\section{Kompi C Lapang-Meulaboh, Menjadi Gudang Sembako Dunia Pasca Tsunami}

Pada hari kedua pasca tsunami, Pemerintahan Kabupaten Aceh Barat belum ada yang mengendalikan. Sementara itu, proses penanganan kondisi darurat diambil alih oleh pihak Korem 012/TU dibawah Komando Kolonel Geerhan Lantara, dengan membuka Posko penanganan darurat di Kompi C Lapang. Suasana Kompi C lapang saat itu telah menjadi gudang sembako dunia, setiap hari dalam setiap jam bahkan dalam hitungan menit, Helikopter terbang bergantian dari negara-negara luar untuk mensuplai sembako di Kompi C Lapang, untuk selanjutkan dibagikan kepada masyarakat Aceh Barat.

Pada saat itu, setiap malam dilaksanakan rapat koordinasi di Kompi C Lapang untuk melihat sejauhmana upaya yang dapat dilakukan untuk menangani masalah darurat tersebut. Kebijakan penting yang dilakukan pertama sekali adalah evakuasi korban yang sudah meninggal dunia. Kedua, kebutuhan makanan bagi pengungsi. Ketiga, mengkonsentrasikan para pengungsi kebeberapa titik seperti Kantor Bupati, sarana pendidikan (antara lain STM, SMA Negeri 1) dan di Suak Raya. Serta yang tidak kalah pentingnya yaitu memberikan rasa aman kepada korban dari tindakan penjarahan.

Berdasarkan keterangan H. Teuku Dadek, pada 27 Desember 2004, Pj. Bupati Aceh Barat Syahbuddin BP menggelar rapat di Posko Kompi C Lapang. Rapat tersebut diketuai Kamandan Korem 012/TU dan Syahbuddin BP sebagai wakilnya. Rapat tersebut menghasilkan keputusan dan menunjuk Kolonel (Purn) Tjoet Agam sebagai Koordinator Tim Evakuasi dan pembersihan kota, khususnya penanganan mengevakuasi mayat. Danrem 012/TU, Kolonel Geerhan juga melakukan konsolidasi terhadap seluruh aparat yang ada baik sipil lokal, pemerintah, swasta dan BUMN seperti Telkom, PLN, dan lainnya. Selain itu, Posko juga dimanfaatkan sebagai tempat penerimaan tamu dari berbagai negara seperi Singapore dan Lembaga Palang Merah Spanyol, yang kemudian berkonsentrasi untuk masalah penanganan air bersih. Sedanhkan pemerintah Singapore memikirkan pendaratan pasukan untuk Bakti Sosial di Kota Meulaboh. Mereka juga ikut membersihkan kota dan membangun rumah sakit sementara di depan Kantor Bupati. Sementara, bantuan dan relawan mulai berdatangan, diantaranya tim khusus dari markas besar PMI Jakarta yang berjumlah 12 orang dengan menggunakan pesawat perintis Susi Air. 


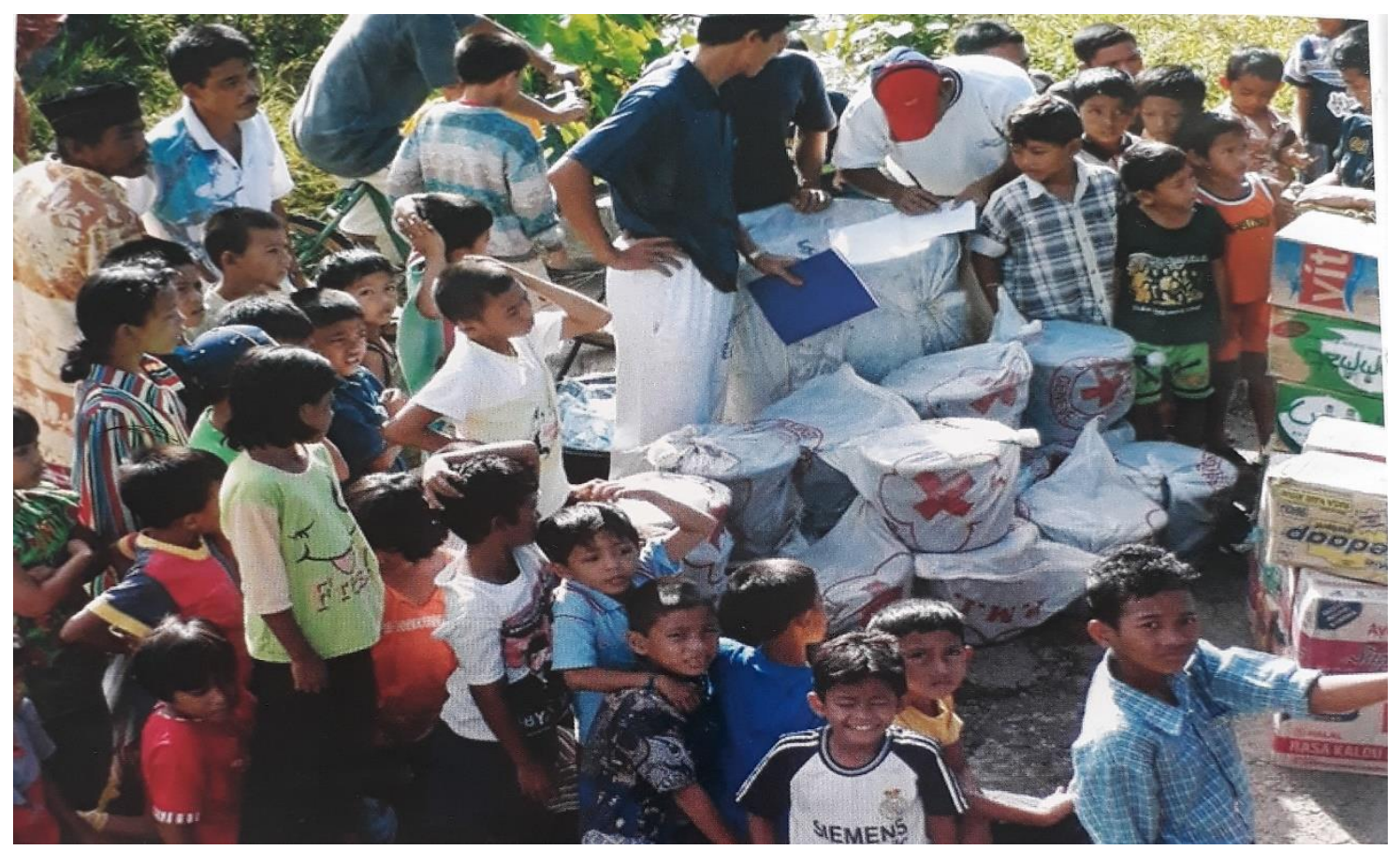

Masyarakat, anak-anak korban tsunami sedang menunggu sembako dibagikan

\section{Penanggulangan Pasca Tsunami}

Penanggulangan pasca tsunami dilakukan meliputi penetapan kebijakan pembangunan yang berisiko timbulnya bencana, kegiatan pencegahan bencana, dan rehabilitasi. Penanggulangan krisis kesehatan akibat bencana adalah serangkaian kegiatan bidang kesehatan untuk mencegah, menjinakkan (mitigasi) ancaman/bahaya yang berdampak pada aspek kesehatan masyarakat, mensiap-siagakan sumber daya kesehatan, menanggapi kedaruratan kesehatan, dan memulihkan (rehabilitasi), serta membangun kembali (rekonstruksi) infrastruktur kesehatan yang rusak akibat bencana secara lintas. Rehabilitasi adalah perbaikan dan pemulihan semua aspek pelayanan publik atau masyarakat sampai tingkat yang memadai pada wilayah pasca bencana dengan sasaran utama untuk normalisasi atau berjalannya secara pedoman teknis penanggulangan krisis kesehatan akibat bencana wajar semua aspek pemerintahan dan kehidupan masyarakat pada wilayah pasca bencana.

Rekonstruksi adalah membangun kembali semua prasarana dan sarana, kelembagaan pada wilayah pasca bencana, baik pada tingkat pemerintahan maupun masyarakat dengan sasaran utama tumbuh dan berkembangnya kegiatan perekonomian, sosial dan budaya, tegaknya hukum dan ketertiban, dan bangkitnya peran serta masyarakat dalam segala aspek kehidupan bermasyarakat pada wilayah pasca bencana. 
Kegiatan pencegahan bencana adalah serangkaian kegiatan yang dilakukan sebagai upaya untuk menghilangkan/mengurangi ancaman bencana. Pencegahan adalah segala upaya yang dilakukan untuk mencegah terjadinya bencana dan/atau bila memungkinkan meniadakan sebagian atau seluruh bencana yang mungkin terjadi.

Mitigasi adalah serangkaian upaya untuk mengurangi risiko bencana, baik melalui pembangunan fisik maupun penyadaran dan peningkatan kemampuan menghadapi bencana. Kesiapsiagaan adalah serangkaian kegiatan yang dilakukan untuk mengantisipasi bencana melalui pengorganisasian serta melalui langkah yang tepat guna dan berdaya guna. Penilaian risiko adalah suatu evaluasi terhadap semua unsur yang berhubungan dengan pengenalan bahaya serta dampaknya terhadap lingkungan tertentu.

\section{Kesehatan lingkungan pasca tsunami}

Faktor penyebab yang paling banyak mempengaruhi kesehatan korban tsunami ialah adanya gangguan lingkungan yang diakibatkan oleh gelombang besar tsunami. Selain itu, lingkungan sekitar harus segera di perbaiki terutama untuk pengungsian, pelayanan kesehatan maupun kegiatan lainnya yang dibutuhkan bagi para korban. Gangguan kesehatan lingkungan serta dampaknya. Jenazah dan bangkai hewan Menurut buku terbitan Organisasi Kesehatan Sedunia (WHO), "Environmental Health in Emergencies and Disaster: a Practical Guide, bahwa jenazah umumnya tidak menimbulkan gangguan kesehatan serius, kecuali jika mencemari sumber air minum dengan tinja atau terinfeksi oleh tifus atau pes yang bisa disebarkan lalat. Kutu jenazah tidak menimbulkan ancaman kesehatan jika ditangani secara benar, dikarenakan kuman penyakit tidak bertahan lama dalam tubuh manusia yang telah mati, kecuali HIV yang bisa bertahan sampai enam hari.

Selain itu, petugas yang menangani jenazah berisiko tertular tuberkulosis, penyakit yang menular lewat darah (hepatitis B dan C serta HIV) serta infeksi pencernaan. Tuberkulosis bisa menular melalui udara jika kuman terbang ke udara dari sisa udara di paru jenazah, paparan penyakit melalui darah terjadi jika ada kontak langsung dengan cairan tubuh atau darah korban.

\section{Penyebab Terjadinya Tsunami}

Berdasarkan studi dan kajian ilmiah, tsunami dapat terjadi jika terjadi gangguan yang menyebabkan perpindahan sejumlah besar air, seperti letusan gunung api, gempa bumi, longsor maupun meteor yang jatuh ke bumi. Namun, 90\% tsunami adalah akibat gempa bumi bawah laut. Dalam rekaman sejarah beberapa tsunami diakibatkan oleh gunung meletus, misalnya ketika meletusnya Gunung Krakatau. Gerakan vertikal pada kerak bumi, dapat mengakibatkan dasar laut naik atau turun secara tiba-tiba, yang mengakibatkan gangguan keseimbangan air yang berada di atasnya. Hal ini mengakibatkan terjadinya aliran 
energi air laut, yang ketika sampai di pantai menjadi gelombang besar yang mengakibatkan terjadinya tsunami.

Kecepatan gelombang tsunami tergantung pada kedalaman laut di mana gelombang terjadi, dimana kecepatannya bisa mencapai ratusan kilometer per jam. Bila tsunami mencapai pantai, kecepatannya akan menjadi kurang lebih $50 \mathrm{~km} / \mathrm{jam}$ dan energinya sangat merusak daerah pantai yang dilaluinya. Di tengah laut tinggi gelombang tsunami hanya beberapa $\mathrm{cm}$ hingga beberapa meter, namun saat mencapai pantai tinggi gelombangnya bisa mencapai puluhan meter karena terjadi penumpukan masa air. Saat mencapai pantai tsunami akan merayap masuk daratan jauh dari garis pantai dengan jangkauan mencapai beberapa ratus meter bahkan bisa beberapa kilometer.

Gerakan vertikal ini dapat terjadi pada patahan bumi atau sesar. Gempa bumi juga banyak terjadi di daerah subduksi, dimana lempeng samudera menelusup ke bawah lempeng benua.

Tanah longsor yang terjadi di dasar laut serta runtuhan gunung api juga dapat mengakibatkan gangguan air laut yang dapat menghasilkan tsunami. Gempa yang menyebabkan gerakan tegak lurus lapisan bumi. Akibatnya, dasar laut naik-turun secara tiba-tiba sehingga keseimbangan air laut yang berada di atasnya terganggu. Demikian pula halnya dengan benda kosmis atau meteor yang jatuh dari atas. Jika ukuran meteor atau longsor ini cukup besar, dapat terjadi megatsunami yang tingginya mencapai ratusan meter.

Gempa yang menyebabkan tsunami

1. Gempa bumi yang berpusat di tengah laut dan dangkal $(0-30 \mathrm{~km})$

2. Gempa bumi dengan kekuatan sekurang-kurangnya 6,5 skala richter

3. Gempa bumi dengan pola sesar naik atau sesar turun

\section{Sistem Peringatan Dini}

Banyak kota-kota di sekitar Pasifik, terutama di Jepang dan juga Hawaii, mempunyai sistem peringatan tsunami dan prosedur evakuasi untuk menangani kejadian tsunami. Bencana tsunami dapat diprediksi oleh berbagai institusi seismologi di berbagai penjuru dunia dan proses terjadinya tsunami dapat dimonitor melalui perangkat yang ada di dasar atu permukaan laut yang terknoneksi dengan satelit. Perekam tekanan di dasar laut bersama-sama dengan perangkat yang mengapung di laut dapat digunakan untuk mendeteksi gelombang yang tidak dapat dilihat oleh pengamat manusia pada laut dalam. Sistem sederhana yang pertama kali digunakan untuk memberikan peringatan awal akan terjadinya tsunami pernah dicoba di Hawai pada tahun 1920-an. Kemudian, sistem yang lebih canggih dikembangkan lagi setelah terjadinya tsunami besar pada tanggal 1 April 1946 dan 23 Mei 1960. Amerika serikat membuat Pasific Tsunami Warning Center pada tahun 1949, dan menghubungkannya ke jaringan data dan peringatan internasional pada tahun 1965. Salah satu sistem untuk menyediakan peringatan dini tsunami, CREST Project, dipasang di pantai 
Barat Amerika Serikat, Alaska, dan Hawai oleh USGS, NOAA, dan Pacific Northwest Seismograph Network, serta oleh tiga jaringan seismik universitas.

Hingga kini, ilmu tentang tsunami sudah cukup berkembang, meskipun proses terjadinya masih banyak yang belum diketahui dengan pasti. Episenter dari sebuah gempa bawah laut dan kemungkinan kejadian tsunami dapat cepat dihitung. Pemodelan tsunami yang baik telah berhasil memperkirakan seberapa besar tinggi gelombang tsunami di daerah sumber, kecepatan penjalarannya dan waktu sampai di pantai, berapa ketinggian tsunami di pantai dan seberapa jauh rendaman yang mungkin terjadi di daratan. Walaupun begitu, karena faktor alamiah, seperti kompleksitas topografi dan batimetri sekitar pantai dan adanya corak ragam tutupan lahan (baik tumbuhan, bangunan dan lain-lain), perkiraan waktu kedatangan tsunami, ketinggian dan jarak rendaman tsunami masih belum bisa dimodelkan secara akurat.

\section{Sistem Peringatan dini di indonesia}

Pemerintah Indonesia, dengan bantuan negara-negara donor, telah mengembangkan Sistem Peringatan Dini Tsunami Indonesia (Indonesian Tsunami Early Warning System - InaTEWS). Sistem ini berpusat pada Badan Meteorologi, Klimatologi, dan Geofisika (BMKG) di Jakarta. Sistem ini memungkinkan BMKG mengirimkan peringatan tsunami jika terjadi gempa yang berpotensi mengakibatkan tsunami. Sistem yang ada sekarang ini sedang disempurnakan. Kedepannya, sistem ini akan dapat mengeluarkan 3 tingkat peringatan, sesuai dengan hasil perhitungan Sistem Pendukung Pengambilan Keputusan (Decision Support System - DSS).

Pengembangan Sistem Peringatan Dini Tsunami ini melibatkan banyak pihak, baik instansi pemerintah pusat, pemerintah daerah, lembaga internasional, lembaga non-pemerintah. Koordinator dari pihak Indonesia adalah Kementerian Negara Riset dan Teknologi (Ristek). Sedangkan instansi yang ditunjuk dan bertanggung jawab untuk mengeluarkan info gempa dan peringatan tsunami adalah BMKG (Badan Meteorologi, Klimatologi dan Geofisika). Sistem ini didesain untuk dapat mengeluarkan peringatan tsunami dalam waktu paling lama 5 menit setelah gempa terjadi. Sistem peringatan dini memiliki 4 komponen: Pengetahuan mengenai bahaya dan resiko, peramalan, peringatan, dan reaksi. Observasi (Monitoring gempa dan permukaan laut), Integrasi dan diseminasi informasi, kesiapsiagaan.

\section{Cara Kerja}

Sistem peringatan dini tsunami adalah merupakan rangkaian sistem kerja yang rumit dan melibatkan banyak pihak secara internasional, regional, nasional, daerah dan bermuara di Masyarakat. Apabila terjadi suatu gempa, maka kejadian tersebut dicatat oleh alat seismograf (pencatat gempa). Informasi gempa (kekuatan, lokasi, waktu kejadian) dikirimkan melalui satelit ke BMKG Jakarta. Selanjutnya BMG akan mengeluarkan Info gempa yang disampaikan melalui peralatan teknis secara 
simultan. Data gempa dimasukkan dalam DSS untuk memperhitungkan apakah gempa tersebut berpotensi menimbulkan tsunami. Perhitungan dilakukan berdasarkan jutaan skenario modelling yang sudah dibuat terlebih dahulu. Kemudian, BMKG dapat mengeluarkan Info Peringatan Tsunami. Data gempa ini juga akan diintegrasikan dengan data dari peralatan sistem peringatan dini lainnya (GPS, BUOY, OBU, Tide Gauge) untuk memberikan konfirmasi apakah gelombang tsunami benar-benar sudah terbentuk. Informasi ini juga diteruskan oleh BMKG. BMKG menyampaikan info peringatan tsunami melalui beberapa institusi perantara, yang meliputi (Pemerintah Daerah dan Media). Institusi perantara inilah yang meneruskan informasi peringatan kepada masyarakat. BMKG juga menyampaikan info peringatan melalui SMS ke pengguna ponsel yang sudah terdaftar dalam database BMKG. Cara penyampaian Info Gempa tersebut untuk saat ini adalah melalui SMS, Facsimile, Telepon, Email, RANET (Radio Internet), FM RDS (Radio yang mempunyai fasilitas RDS/Radio Data System) dan melalui Website BMG (www.bmg.go.id).

Pengalaman serta banyak kejadian dilapangan membuktikan bahwa meskipun banyak peralatan canggih yang digunakan, tetapi alat yang paling efektif hingga saat ini untuk Sistem Peringatan Dini Tsunami adalah Radio. Oleh sebab itu, kepada masyarakat yang tinggal di daerah rawan tsunami diminta untuk selalu siaga mempersiapkan Radio FM untuk mendengarkan berita peringatan dini tsunami. Alat lainnya yang juga dikenal ampuh adalah Radio Komunikasi Antar Penduduk. Organisasi yang mengurusnya adalah RAPI (Radio Antar Penduduk Indonesia). Mengapa Radio? jawabannya sederhana, karena ketika gempa seringkali mati lampu tidak ada listrik. Radio dapat beroperasi dengan baterai. Selain itu karena ukurannya kecil, dapat dibawa-bawa (mobile). Radius komunikasinyapun relatif cukup memadai.

\section{PENUTUP}

\section{Kesimpulan}

Pembahasan yang telah diuraikan diatas dapat disimpulkan bahwa peristiwa besar yang dialami daerah di Provinsi Aceh, gempa besar dan tsunami 26 Desember 2004 lalu, permasalahannya sangatlah beragam, seperti terganggunya kesehatan masyarakat Aceh maupun kesehatan lingkungan setelah terjadinya tsunami. Upaya penanggulangan dan pencegahan permasalahan kesehatan pasca tsunami, yaitu penanganan jenazah yang baik, perbaikan dan pengawasan kualitas air bersih, pengendalian kesehatan lingkungan pengungsian, serta pengawasan dan pengamanan makanan dan minuman. Selain itu, perencanaan pasca tsunami sebagai upaya meminimalkan dampak pasca tsunami maupun bencana yang akan terjadi di masa mendatang. Misalnya penggalakkan hutan mangrove, kontruksi tahan gempa dan perencanaan yang lainnya.

Tsunami adalah rangkaian gelombang laut yang mampu menjalar dengan kecepatan hingga lebih $900 \mathrm{~km}$ per jam, terutama diakibatkan oleh gempa bumi yang terjadi di dasar laut. Tsunami dapat terjadi jika terjadi gangguan yang menyebabkan perpindahan sejumlah besar air, seperti letusan gunung api, gempa 
bumi, longsor maupun meteor yang jatuh ke bumi. Sistem peringatan dini adalah suatu system atau alat yang digunakan untuk mengirimkan peringatan tsunami jika terjadi gempa yang berpotensi mengakibatkan tsunami.

\section{DAFTAR PUSTAKA}

Walter c. Dudley dan min lee, tsunami, 2006, penerbit: university of hawaii press

Syeikh muhammad mutawalli asy-syàrawi, meraih Hikmah Dibalik Peristiwa Gempa Bumi, 2005, Penerbit: Pustaka Ulumuddin, Bandung.

Teuku Dadek, Gempa dan ie Beuna Aceh Barat, Penerbit Bappeda Aceh Barat, 2015

Kompas Media Nusantara. 2005, Bencana Gempa Dan Tsunami Nanggroe Aceh Darussalam \& Sumatera Utara. Jakarta : Penerbit Buku Kompas.

Kementrian Agama RI, 2012. Penciptaan Bumi Dalam Perspektif Al-Qur'an dan Sains. Jakarta : Kementrian Agama RI 